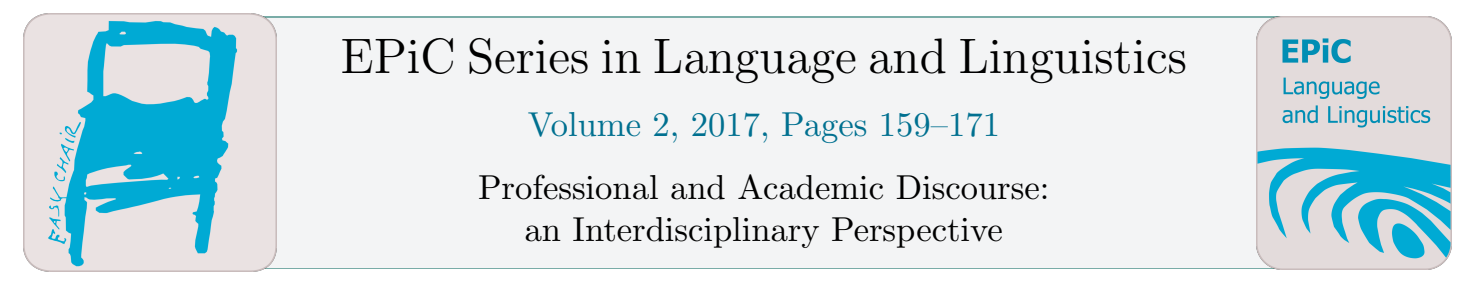

\title{
Identity and the Indexicality of Code-switching in the Egyptian Society
}

\author{
Rasha S. Mohamed \\ The American University in Cairo, Cairo, Egypt \\ rashasoliman@aucegypt.edu
}

\begin{abstract}
This sociolinguistic paper analyzes the linguistic codes used in the Egyptian television series A Girl Called Zaat (Zaat), which was produced in 2013. This series is an adaptation of the novel Zaat or self by the leftist Egyptian novelist Son'a Allah Ibrahim. The series was chosen because it depicts the eras of several Egyptian presidents, and thus is abundant of important political and social events in Egypt, from the 1952 revolution to the 2011 revolution. These political and social incidents were very influential in the life of the heroine "Zaat", who represents Egyptians. It would be useful to examine how language was used to express the changes that were taking place in the Egyptian society and hence in Egyptian people's identities. This research attempts to answer these questions: What were the codes used in the series? What were the indexes of these codes? How was Codeswitching (CS) related to identity? Language and identity have a strong relationship and a reciprocal influence. The Theory of indexicality was used in the analysis, particularly second and third order indexicality. The analysis revealed that there were three codes in the series: Egyptian Colloquial Arabic (ECA), English, and Standard Arabic (SA). Hopefully, by examining the indexes of these three codes, the analysis of this series would be of interest and benefit in highlighting the Egyptian social and linguistic situation.

Keywords: Sociolinguistics, Code-switching, Indexicality, Identity, Egyptian, television series.
\end{abstract}

\section{Introduction}

\subsection{Background of the Study}

Code-switching (CS) is switching between two different languages or two varieties of the same language (Gumperz, 1982; Myers-Scotton, 1993a; Myers-Scotton, 2010). It occurs in almost all forms of language; written, spoken, as well as sign languages (Bullock \& Toribio, 2009). CS has been studied from different perspectives, including the psycholinguistic and sociolinguistic (Gumperz, 1982; Nilep, 2006). Reasons for CS vary; sometimes people resort to it because they are not completely proficient in 
one language and feel more eloquent in another language (Bassiouney, 2009; Myers-Scotton, 1993b). In other cases people use CS for accommodation purposes. However, this is not always the case because interlocutors may use CS for a word they are familiar with in both codes and without a need for accommodation (Myers -Scotton, 1993a). Omoniyi and White (2006) suggested that CS can also be used to give context to communication by providing information that exceeds the linguistic reference like reflecting a certain identity, or designating change in social roles (Gumperz, 1982; Nilep, 2006), or as Myers-Scotton (1976) indicated, creating social distance. In addition, people resort to CS as a means of expressing belonging to a certain group or having specific origins (Bullock \& Toribio, 2009; Suleiman, 2004).

Two main concepts that form the background for this study are: identity and the theory of indexicality. Identity has various kinds and several definitions; personal, national, and social identities. Edwards (2009) mentioned that even the simplest things create links between people and make them form a group. One of the absurd things about identity is how it is the means of forming groups, yet at the same time it is what makes each individual unique, as it is pretty hard to find two people who have identical identities. Language and identity have a strong relationship and a reciprocal influence. To illustrate, hearing someone's speech can tell a lot about his/her nationality, local city, level of education, stance, and dispositions in life. Language seems powerful here as it is correlated to all the types of identity. It also works the other way round, knowing someone's identity makes us expect a certain language to be used. Moreover, languages are alive and are constantly changing just like identities.

Indexicality is the association of codes; each linguistic code has its indexes. These associations or indexes are highly dependent on the context and are not fixed (Jaffe, 2009; Myers-Scotton, 2010). Therefore, the same code can have both positive and negative indexes depending on the situation itself. Myers-Scotton (1993a) called it a "love/hate attitude" (p. 30) and narrated two situations of the use of English in Kenya that yielded opposing results. In the first situation, English was indexed as the language of the elite and allowed the speaker to enter the police station and even free a relative of his, while in the second situation, speakers of English were thrown out of a beer party as they were viewed as being conceited.

There are different degrees of indexicality (Silverstein, 2003): First order indexicality which is not noticeable or intentional since it happens naturally, second order indexicality which is more creative and noticeable as it serves in denoting belonging to a certain group, and third order indexicality which is very creative and performative as it goes beyond belonging to one group. For example, when someone who was born and raised abroad comes to Egypt and speaks English, this is referred to as first order as it is normal and expected. However, if this person knows Arabic very well and intentionally does not use it, that is second order indexicality as it means this person shows belonging to another group than Egyptians. An example of third order indexicality was given by Bassiouney (2014) when she described a journalist who had used her Alexandrian variety to denote belonging to Alexandria as well as to show religious tolerance, since she related to all Alexandrians regardless of their religion. In this paper second and third orders were of primary interest.

\subsection{Statement of the Research Problem}

Most studies of CS have examined structure or frequency of CS, while very few have analyzed the functions of CS. CS to English has scarcely been examined in a context where Arabic is the main language of communication and it has not been studied in Egyptian television series before. In this study CS in an Egyptian series was analyzed in relation to identity and indexicality. It would be useful to employ the theory of indexicality to examine how screenwriters deploy CS to reveal the identity of characters. 


\subsection{Research Questions}

The study intended to answer the following research questions:

1. What are the linguistic codes that were used in Zaat television series?

2. What are the indexes of these linguistic codes that were used in Zaat television series?

3. How was identity related to code-switching in Zaat television series?

\section{Literature Review}

Many studies have examined CS as spoken (Albakry \& Hancock, 2008; Sebba, Mahootian, \& Jonsson, 2012), yet these studies of spoken CS had different points of foci and did not relate CS to identity or indexicality. This literature review is divided thematically into two parts: previous research related to CS and contextualizing the study. The first part presents studies of CS as it examines studies that analyzed CS and applied the theory of indexicality to the two varieties of Arabic in Egypt (SA and ECA) as well as to English in India. As for the second part, it deals with the use of ECA, English, and SA in the Egyptian society.

\subsection{Part One: CS Research}

Albirini (2011) focused on CS between SA and different dialects, data was collected from both formal and informal contexts. The three dialects that Albirini chose were Egyptian, Gulf, and Levantine Arabic, the contexts he selected for data collection were: religious sermons, political debates, and soccer commentaries. Albirini found that CS is mainly linked to the indexes of the codes themselves and how speakers view them more than the situation itself. He also shed light on identity, the link between SA and Arab-Muslim identity, and recommended investigating the issue of identity in further studies. Regarding the indexes of English, two studies revealed some of the indexes of English in India by examining CS between Hindi and English. Bhatt (2008) studied two English newspapers in India and instances of CS to Hindi in these newspapers over the span of five years from 2001 to 2006. He started by giving background about the position of English in India as the language of the colonizer, yet also the language of the upper classes and good opportunities for work. This can be referred to as the different indexes of English in the Indian society, which are also correct regarding its position in Egypt. He also shed light on the political situation in India at the time of the study, which is important to account for the increase in the use of Hindi in English newspapers. Bhatt argued that CS to Hindi created a new area, which he referred to as third space, for people who wanted a compromise between modernity (English) and tradition (Hindi).

Gokarn (2008) also worked on CS between Hindi and English, but in Indian television advertisements. Gokarn chose advertisements from the mid 90s till 2007 to find the objective for CS between English and Hindi, or what he referred to as the use of Hinglish. The researcher chose advertisements for various products, such as: soft drinks, watches, and skin products. The script of these ads was analyzed and some screen shots of the ads were included for demonstration. Like Bhatt (2008), Gokarn gave some background about the linguistic arena in India and how English is widely used especially by the youth, yet Gokarn did not discuss the negative indexes of English in India. Gokarn relied on the positive indexes of English to explain the reasons for using Hinglish. For instance, English is related to science and progress, which makes Hinglish beneficial to market various products and to deliver the message to customers that this product is of value. In addition, English is associated with the developed West and prestige, which is a positive image businessmen would be keen on linking to the image of their products in customers' minds. 


\subsection{Part Two: Contextualizing the Study}

Arab countries are diglossic communities (Ferguson, 1959), which means there are at least two different varieties of Arabic used in these communities. In addition to Standard Arabic (SA) that is shared by all Arab countries, each country has its own vernacular (Bassiouney, 2010; Bassiouney, 2015). In Egypt, the official language is Arabic as stated in the Egyptian constitution ("Chapter One," 1980). This part accounts for the use of ECA, SA, and English.

ECA is the language of communication among Egyptians (Doss, 2010). SA is taught in schools, and since the illiteracy percentage is high in Egypt, many Egyptians especially people that work in handicrafts cannot read or write SA. A website that gives advice about traveling overseas gave some examples of sentences tourists can use in Egypt. "Do you speak English?" in ECA is rendered as "betekkallem 'engelizi? (addressing a male)", while if it were in SA it would have been Hal tatakalam alenjili:z'ia? ("Languages in Egypt," n.d.). ECA is also used in movies and the vast majority of television talk shows. Therefore, it is associated with intimacy, friendliness, and informality (Bassiouney, 2009, 2014).

English is taught in almost all Egyptian schools. In public schools, it is taught from grade one, while in private and international schools, it is taught from kindergarten and on a deeper level than public schools. English is also evident on television, as Channel Two and Nile TV broadcast news and programs in English. There is also Nile FM (104.2) radio station that is always in English and receives phone calls that are conducted in English. Moreover, English is widely used in the streets and on shop signs. English indexes that the speaker has received a good education, comes from a high socioeconomic status, or has been brought up in a developed foreign country. On the other hand, English is historically associated with the British colonization in Egypt (Bassiouney, 2009, 2014). People went very far in relating English to foreign countries to the extent that during the January $25^{\text {th }}$ revolution, some of them accused protesters who spoke English of being spies and conspiring against their own country. In 2014, Youm7 newspaper, along with other newspapers like Al Ahram, reported an incident of two men being arrested in a metro station just because they were talking in English ("Egypt's most bizarre," 2014). However, this situation was very strange and was ridiculed by many Egyptians on Facebook and other social media, which reveals the contradictory indexes a language can have.

SA is related to education, history, and Islam, specifically the Qur'an. It is taught in all schools whether public, private, or international. At the university, academic books that are in Arabic are written in SA. As for the relation between SA and Islam, most preachers depend on SA in their sermons (Doss, 2010). The Egyptian radio station The Holy Qur'an, which broadcasts religious programs and recitations from the Qur'an, uses SA abundantly in its programs. SA is mentioned in religious texts and by preachers that one of the marvels of the Qur' an is that it was sent to people in Kingdom of Saudi Arabia, who mastered Arabic and appreciated poetry to a great extent. These people were amazed at the eloquence of the Qur'an and their trials to compose anything like it failed, in spite of their prominent linguistic skills. Thus Muslims do not like to change the language of the Qur'an. It is worth noting that the Arabic of the Qur'an is referred to as classical Arabic and is hardly used by anyone, so sheikhs resort to SA to explain and interpret Qur'anic verses after reciting them in classical Arabic. Associating SA to religion is also evident in movies. Whenever a series or movie is made about a certain religious figure or an important era in Islamic history, SA is the predominant language in use in these works of art, such as the movies Dawn of Islam and Al Shimaa. 


\section{Methodology}

The present study is a descriptive as well as a corpus-based study, which uses linguistic analysis of the corpus to reach conclusions. All the data that was collected was analyzed linguistically. It is believed that such a design suits the nature of the research questions and accounts for the functions of CS.

\subsection{Source of Data}

Data was collected from a TV series for the famous screenwriter Mariam Naoum A Girl Called Zaat (2013) or Self, which is an adaptation for the novel Zaat, by the leftist Egyptian novelist Son'a Allah Ibrahim. The title, which is the name of the female protagonist, implies a focus on the identity of the Egyptian heroine who is believed to represent the life of most Egyptian women or even symbolize Egypt. The series starts with Zaat's birth July 23, 1952, which coincides with the Egyptian revolution, and continues in narrating her life until the January 25, 2011 revolution. Thus, the series covers the eras of three main presidents: Gamal Abdel Nasser, Mohamed Anwar El Sadat, and Mohamed Hosni Mubarak. She is full of hopes at the beginning of her life, yet all her dreams are crushed by the severe reality she has to endure and the lack of understanding between her and her husband. The series depicts the sufferings of Zaat's family on different levels, such as: the financial, educational, medical, and professional levels. Therefore, Zaat is rich with criticism of the condition of the Egyptian society. Zaat was chosen for data analysis because it includes CS between three linguistic codes, ECA, English, and SA. It would be the first study to analyze CS between Arabic and English where Arabic is the matrix language and English is the embedded one. Furthermore, the series' focus on social and political news that took place in Egypt provided good commentaries on the characters' different identities.

\subsection{Procedure for Data Collection}

After watching the series, the major instances of CS were collected and analyzed whether this switch was between Arabic and English or between ECA and SA. To better understand the indexes of CS in relation to identity, context was highlighted as it is of huge importance, which Fishman (1989) referred to as occasion, event, and interlocutor. In addition, the linguistic pattern each character followed while speaking was traced. What is meant by pattern is the code that the character used most of the time to emphasize the significance of CS when it took place. After collecting and analyzing data, the International Phonetic Alphabet (IPA) was used for transcription of the data to make the differences between codes clear. By the use of IPA non-Arabic speakers will be able to read the examples and see the differences between SA and ECA. To answer the research questions, the theory of indexicality was applied to CS and some linguistic strategies or resources, such as pronouns and presuppositions, were employed to overcome the shortcoming of indexicality easily lending itself to subjectivity. 


\section{Analysis and Discussion}

Analysis showed that there were three linguistic codes: ECA, English, and SA. ECA was the predominant linguistic code in the series. Given that ECA is used in Egyptians' daily interaction, and the series was addressed to the masses of people to watch at home, it makes sense to use ECA abundantly.

\subsection{Indexes of ECA and the Relationship between CS and Identity}

The indexes of ECA were: daily interaction, authenticity, and belonging to Egyptians as table 1 shows. The first index was first order indexicality as its use was predictable and normal since Egyptians speak in ECA. It also indexed authenticity, as it was the code characters used when they were being themselves and not bragging about their status.

\begin{tabular}{lll}
\hline Code & Index & View of the index \\
\hline ECA & Daily interaction & Positive, Negative \\
& Authenticity & Positive \\
& Belonging to Egyptian masses & Positive \\
\hline
\end{tabular}

Table 1: Indexes of ECA

The index of being one of the people was clear when Azeez, a political activist university student, held signs in ECA. It was common to use SA in politics, yet he said in his speech:

"Ga:yzi:n niha:rib" "we want to go to war".

He also used ECA in the signs he held:

"Hanha:rib” "we will go to war",

"Ya:yzi:n șaha:fa horra” "We want free press"

At that time, president Sadat announced that Egypt would not fight Israel, who trespassed on the Egyptian territory in Sinai. The aim of Azeez's speech and the university demonstrations he led was to gather students around him and oppose the president's decision. In such an important situation, ECA was the best linguistic code as it is closer to the hearts of Egyptians and the use of the pronoun "we" supported belonging to the masses. There was also presupposition from Azeez's part that all Egyptians agreed and sought the same demands he wanted. This finding correlates with (Bassiouney, 2006, 2013) where there was an attempt from politicians and religious men to get closer to the Egyptian people by switching to ECA in their speeches and sermons.

\subsection{Indexes of English and the Relationship between CS and Identity}

English had several indexes that varied between positive or negative according to the situation and the speaker. Several characters in the series used English: Zaat's husband, her friends, son, and two nephews. These indexes are summarized in table 2. 


\begin{tabular}{lll}
\hline Code & Index & View of the index \\
\hline English & Good education & Positive \\
& \$Loss of identity & Negative \\
& Social prestige & Negative, Positive \\
& Developed countries & Positive \\
& Affiliation with the West & Negative \\
\hline
\end{tabular}

Table 2: Indexes of English

Episode four witnessed the first appearance of Zaat's future husband AbdelMegeed. He was presented as a silly character that none of the family liked, even Zaat herself, except for the mother who saw in him a suitable groom for her daughter. Abdel Megeed always used the English word 'of course' in his speech to show that he had good education and a privilege over others. He even claimed to master the English language and to be planning to learn French, yet he never did. He mostly used simple words like:

"Of course, of course not, and never ever".

Zaat's father even laughed at him by giving him the title "Abdel Megeed of course". One has to doubt AbdelMegeed's mastery of English as he never used a complete sentence, he did not have a university degree, and in the rare occasions he uttered other words than 'of course' they were mispronounced. For instance,

'wait' was pronounced as /wi:t/

'th' in the word 'anything' was pronounced as /s/.

Thus, his use of code-switching was to make use of the indexes of English as the code of prestige and good education especially since AbdelMegeed did not get a college degree.

In episode five, there was an interesting scene during the engagement party of Zaat and AbdelMegeed where language played a role in showing each character's stance towards major political occurrences in the Egyptian society. A friend who has just returned from the US thought that Egypt was not ready for war with Israel and AbdelMegeed agreed with him. On the other side, were Azeez and his wife Safiyya, who were both political activists and led protests against Sadat at that time (August 1973) for not fighting Israel. The speakers in the first group used the English word really to express their opinion while Safiyya shouted at them:

"Really ?eih?!!" "What really?!!"

and argued for the sake of having dignity and reclaiming the Egyptian land. It can be argued that the indexicality of English here meant being pro Western thought in a negative sense. It is worth mentioning that Zaat, who was always passive and did not take sides, remained silent and neither spoke in English nor in Arabic.

Another character that appeared and spoke English was Zaat's son. When he was born, his father was extremely happy to finally have a boy after two girls and called him "Amgad" which came from 'Magd' that means glory. The son was born in a very tough time when AbdelMegeed lost all the money he has saved from his years of hard work in an Arab gulf country. AbdelMegeed also went to prison because of an unjust report filed against him from a corrupt employee in the government. Amidst all these problems Zaat discovered her son's inability to speak and took him to a speech therapist, but in vain. Here silence reflected the new generation's feelings towards a corrupt society full of injustice, Amgad did not utter one single word because he felt helpless and unable to hope for a better future.

Amgad's first word was after his father was out of prison and surprisingly he only spoke English

'I am hungry'.

AbdelMegeed was thrilled and so proud of his son to the extent of calling him a 'genius' and those who did not understand him were 'backward' which indexes the superiority of foreign languages to Arabic. On the other hand, Zaat saw this as a big problem and wanted her son to speak Arabic. The 
whole family tried to teach him Arabic through interesting means such as: stories, children's songs, movies, and the news paper, but the kid was so resistant to all these efforts and even got furious when they forced him to watch Arabic movies. This rejection to speak Arabic indexes the rejection of the whole culture and the society as well. If AbdelMegeed looked up to English and inserted some words in his speech, he was still proud of his Egyptian identity, yet for Amgad he was only speaking English. This reflects the severe change in the relationship between the new generation and their country; in other words their national identity.

In episode twenty-four, there was a scene in a public school that indexed the importance of language for identity. Amgad spoke in English

"I love you, dad!"

The school principal's reaction was to refuse accepting Amgad because of his inability to speak Arabic, and of course Zaat could not afford to educate her son in an international school, so AbdelMegeed argued that this was his son's right as an Egyptian citizen. The principal said, "I owe this right to Egyptians who speak Arabic, but your son is a foreigner bearing an Egyptian ID". The principal's stance toward the young boy was that he did not belong to the Egyptian society because he did not speak the same language as Egyptians.

In episode twenty-six, Zaat's brother, Hassan, who has immigrated to the US and never came back, even when his father was seriously ill, came back to visit Egypt with his wife and two sons. Hassan's pronouns reflected being Egyptian was not part of his identity anymore. He said about Egypt,

"How do you live in this country?! ...I want to be back to my country, America!"

He had two sons who were university students and it was their first time to visit Egypt, their parents' country. These two sons had two completely different stances from Egypt that can be reflected in their language. Mansour who refused to live in Egypt did not speak any Arabic while Saad who loved Egypt code-switched between Arabic and English. Saad told his cousin that during his family's stay in the U.S., he was proud to tell everyone that he was an Arab and spoke Arabic while his brother Mansour considered himself an American and did not use any Arabic. The name itself, 'Saad' is a reminder of the famous Egyptian leader 'Saad Zaghloul' who is a symbol of patriotism.

Saad decided to live in Egypt and did not like the fact that his brother joined the American army in the invasion of Iraq and commented about this saying that his brother chose to be American and lost his identity. Saad argued with his brother Mansour over the phone because of this; he used English to convince his brother that Iraq did not have any nuclear weapons and that he was misled. However when he got really frustrated and lost hope that his brother would listen to him, he shouted at him in real anger,

"From now on when you talk to me, talk in Arabic".

He wanted him to be back to his original identity as an Egyptian who speaks Arabic, which is an evidence of the strong relationship between one's language and identity.

By examining the Egyptian society, one notices the spread of English in schools, jobs, shops, and street signs. Even a kiosk that sells cigarettes and candy has its sign in English, though it is located in Nasr City, an area where the vast majority of residents are Egyptians and speak Arabic (see Figure 1). One of the main reasons for the spread of English in Egypt and other countries is that in terms of power English is a very powerful code and is the current lingua franca. It is the language of science, technology, research, and development, and therefore individuals worldwide are keen on mastering and using it. As was mentioned earlier, the schools that provide good education in Egypt are language and international schools, and the majority of these schools offer education in either American or British English. These schools are much more expensive than the public schools and therefore going to an international school denotes coming from a well-off family. It is also worth mentioning that many of these schools are so selective that they conduct interviews with the parents before accepting their children to make sure they come from "appropriate" social backgrounds. Thus, it is no wonder that Abdel Megeed, who did not finish his college degree, resorted to English to pretend that he belonged to a higher social standard. These indexes of social prestige and good education correlate with studies in other countries where 
English enjoys a similar status, such as: Singo (2014) in Zimbabwe, Bhatt (2008) and Gokarn (2008) in India, and Madonsela (2014) in South Africa.

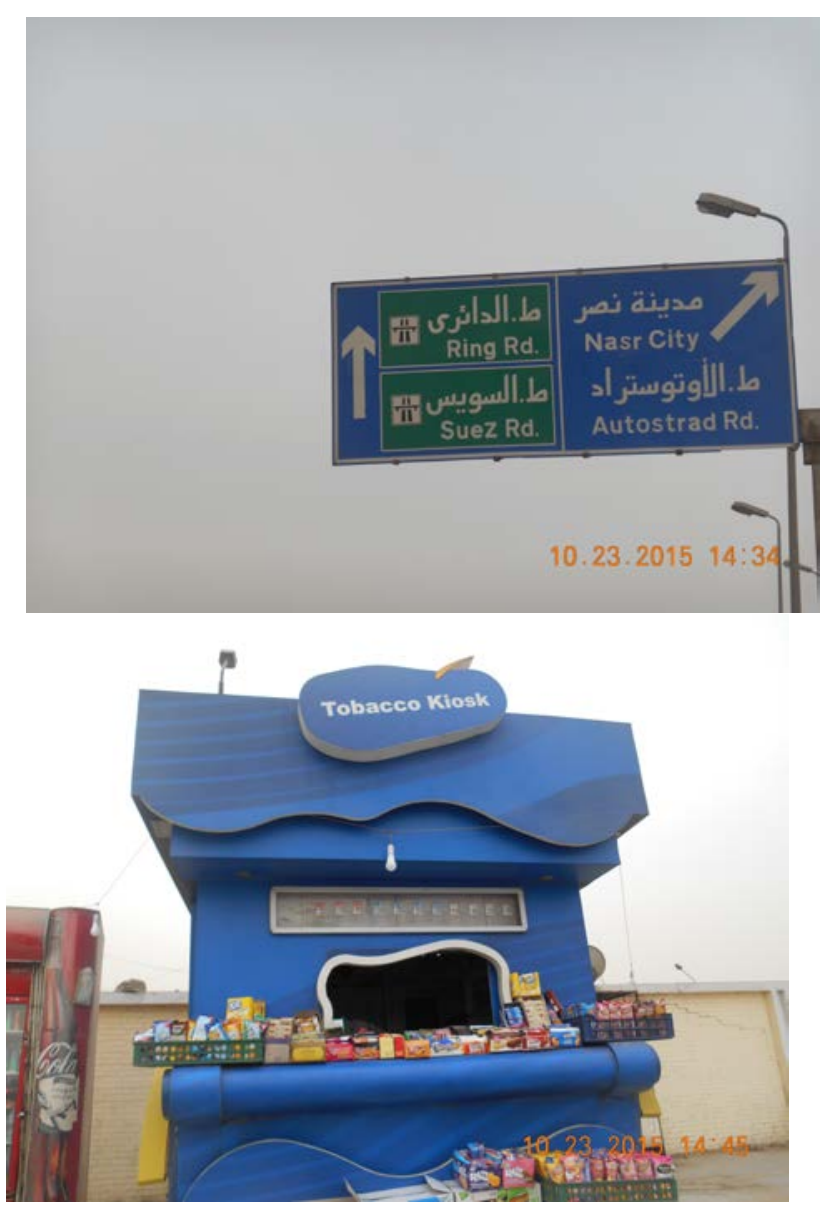

Figure 1: Street sign in both Arabic and English \& kiosk sign in English only in Nasr City, Cairo, Egypt.

One of the main indexes of English is having relations with English language speaking nations like England or the U.S. The negative index that English had in the series was that of alliance with the West at the expense of the welfare of one's own country and its free will, like Zaat's nephew who joined the US army in Iraq. This was the case in Tahrir Square in 2011 when the media cast doubt on the demonstrators' loyalty to Egypt just because there were some signs and slogans that were written in English (Bassiouney, 2012). This was an interesting finding especially since few studies have discussed this negative index of English in their societies. It is also an important finding because it resonates with recent incidents that took place in Egypt in 2012 and 2014 when people speaking English were suspected and considered a source of trouble, first when a parliament member called for banning the teaching of English in schools, claiming that this is a Western conspiracy to erase the Arab identity and the second was when two people were about to be jailed because they were discussing politics in English in the subway. 


\subsection{Indexes of SA and the Relationship between CS and Identity}

SA was used a lot in the news and in political discussions. In episode two, the Egyptian masses were in the streets calling for the downfall of their enemy after it attacked Sinai

"tasqot Israel” "down with Israel”

Though ECA is the code used in daily conversation, people get influenced by political speeches and the news that mostly use SA, and hence people use SA as well. Here it may be argued that SA gives people a sense of authority. That was also the case after January $25^{\text {th }}$, 2011 revolution as many young people and uneducated people kept repeating some SA words and expressions that they only learned from the media. Table 3 indicates the different indexes of SA.

\begin{tabular}{lll}
\hline Code & Index & View of the index \\
\hline SA & Authority & Positive, Negative \\
& Pan Arabism & Positive \\
& Education & Positive \\
& Islam & Positive, negative \\
\hline
\end{tabular}

Table 3: Indexes of SA

The name Zaat is an SA word that means self or the owner of. In AbdelMegeed's first conversation with Zaat he expressed his surprise from her weird name and did not seem to like it, unlike Azeez who admired the name especially that it goes back to a character from history 'princess Zaat El Hemma' as Zaat told him. This stance from the name reflected the juxtaposition in their characters; Azeez was Zaat's colleague at the university, a good reader, and a political activist, unlike AbdelMegeed who was passive and always accepted what the government dictated. The index of SA is being cultivated and well read. SA also indexed good education; which was evident in Azeez's use of SA words in episode two when he was convincing Zaat of volunteering in the program of erasing illiteracy.

In addition, there was also a difference between the father and AbdelMegeed's personalities. To elaborate, the father was not passive and was always into politics and following ardently the important events in Egypt. This was clear in their conversation when AbdelMegeed proposed to Zaat, while AbdelMegeed claimed access to the English language, and kept using English words, the father used words from SA like

'ma:zilt sha:yif' "I still see”

'tafkeer wa tarayu $\theta$ ' "thinking carefully".

The father was a huge fan of president Nasser who called for unity among Arab nations, so he used SA as it indexed pan-Arabism. AbdelMegeed's inclination, on the other hand, was pro-Sadat, who initiated cooperation with the U.S., so he used English frequently. When the close friends and in-laws of Zaat's family decided to immigrate to the U.S., Abdel Megeed saw this immigration and being an American citizen as a great privilege, while Zaat's father fought with his in-laws when they tried to convince him to travel with them. He even accused them of hating their homeland and being less patriotic.

SA also indexed Islam, which was clear in the language of Zaat's son in law, whose personality changed as he became more religious. Whenever he sat with someone, he kept giving him/her religious advice and comments in a way that annoyed his family. He was keen on highlighting the distinction between himself as a religious person, and the rest of the society. This was reflected in his use of SA, for instance when he gave birth to a girl, he named her " $Y a$ :Pisha" and whenever anyone pronounced it in the colloquial way "Yeisha", he would correct him/her to be pronounced in SA, which is closer to Islam. This result conforms with Albirini’s (2011) suggestion of a relation between SA and Islam. 
To sum up, I have examined the language of several important characters in Zaat's family. The analysis of their language focused on CS, indexicality, and identity. The use of indexicality was challenging since it is subjective and requires enough awareness of the background of incidents. However, indexicality is of great importance to understand the meanings behind linguistic choices. It also helps people realize reasons for choosing linguistic resources as well as results of these choices in relation to identity. As Monica Heller (2008) indicated, language is more than form and meaning; it needs to be associated to context and specifically a social one.

\section{Conclusion}

\subsection{Implications of the Study}

It is hoped that this sociolinguistic study provides an insight into language use in Egypt and how choices of different codes, ECA, English, and SA are interpreted. The study has shown that indexes of codes can be positive, negative, or both at the same time. English, for instance, had negative associations when it was used in politics, but was loaded with prestige in social interaction. Moreover, the study has revealed that in the field of politics, speakers tend to manipulate the masses by using the code that is closest to people's daily interaction and the pronoun we to imply that these politicians are united with the Egyptian masses. By shedding light on these indexes, people's awareness of the role of linguistics in influencing them would increase. It would also assist speakers in choosing the most suitable linguistic code depending on the situation. Understanding these indexes of codes and the relation between these codes and identity would provide a clearer picture of the Egyptian linguistic situation.

The implications of this study can also be transferred to teaching languages. English language teachers' awareness of the positive indexes of English in Egypt would help them motivate the learners to master the language and benefit from its prestige, especially that learner motivation is of great importance (Guilloteaux \& Dörnyei, 2008; Moskovsky, Alrabai, Paolini, \& Ratcheva, 2013). Arabic language learners and curriculum designers should also be aware of the fact that indexes of SA differ from the indexes of ECA. If a learner of Arabic aims at specializing in politics or theology, s/he will prioritize learning SA, while if her/his goal of learning Arabic is for communication or tourism, s/he will give priority to ECA. Thus, understanding the connotations of each code could be useful for both teachers and learners.

\subsection{Limitations of the Study}

This study explored examples of CS between ECA, English, and SA in the Egyptian series A Girl Called Zaat. It focused on the connotations of each code used and how CS was deployed to convey certain meanings. In addition, the role of CS in illuminating characters' identities was examined. Limitations of the study include being conducted on one series only. In addition, the study did not include quantitative analysis of different structural types of CS since this structural approach does not account for the reasons or meaning attributable to CS (Nilep, 2006). Moreover, the perspective of viewers on the use of CS in the series was not examined.

\subsection{Recommendations for Future Research}

It is recommended for further research to investigate the relation between CS, identity, and stance. It may also be of use to include, within the scope of studying CS, readers' or viewers' perception and whether they are aware of the meanings CS delivers. Moreover, it can be valuable to examine the indexes of English in other countries as well as the indexes of SA and the local dialects in other Arab countries. 


\section{References}

Albakry, M., \& Hancock, P. H. (2008). Code switching in Ahdaf Soueif's The Map of Love. Language and Literature, 17(3), 221-234.

Albirini, A. (2011). The sociolinguistic functions of codeswitching between Standard Arabic and Dialectal Arabic. Language in Society, 40(5), 537-562.

Bassiouney, R. (2006). Functions of code-switching in Egypt: Evidence from monologues. Leiden: Brill.

Bassiouney, R. (2009). Arabic sociolinguistics. Edinburgh: Edinburgh University Press.

Bassiouney, R. (2010). Redefining identity through language in the literature of the diaspora. Comparative Studies of South Asia, Africa and the Middle East, 30(1), 101-106.

Bassiouney, R. (2012). Politicizing identity: Code choice and stance-taking during the Egyptian revolution. Discourse and Society, 23(2), 107-126.

Bassiouney, R. (2013). The social motivation of code-switching in mosque sermons in Egypt. International Journal of the Sociology of Language, 2013(220), 49-66.

Bassiouney, R. (2014). Language and identity in modern Egypt. Edinburgh: Edinburgh University Press.

Bassiouney, R. (2015). Dialect and stance-taking by non-Egyptian celebrities in Egypt. Open Linguistics, 1(1), doi:10.1515/opli-2015-0022.

Bhatt, R. M. (2008). In other words: Language mixing, identity representations, and third space. Journal of Sociolinguistics, 12(2), 177-200.

Bullock, B. E., \& Toribio, A. J. (2009). Cambridge handbook of linguistic code-switching. Cambridge, UK: Cambridge University Press.

Chapter one: The State. In Egypt's Government Services Portal. Retrieved September 25, 2015, from http://www.egypt.gov.eg/english/laws/constitution/chp_one/part one.aspx

Doss, M. (2010). Hāl id-Dunyā: An Arabic news bulletin in Colloquial ('Āmmiyya). In R. Bassiouney (Ed.), Arabic and the media: Linguistic analyses and applications (1st ed.) (pp. 123-140). Leiden: Brill.

Edwards, J (2009). Language and identity. Cambridge: Cambridge University Press.

Egypt. (n.d.). In Encyclopedia Britannica Online. Retrieved April 15, 2015, from http://www.britannica.com/EBchecked/topic/180382/Egypt/43465/Languages

Egypt's most bizarre news of 2014. (2014, December 29). In Ahram Online. Retrieved September 25, 2015, from http://english.ahram.org.eg/NewsContent/1/64/118977/Egypt/Politics-/Egypts-mostbizarre-news-of-.aspx

Ferguson, C. (1959). Diglossia. Word, 15(2), 325-340.

Fishman, J. A. (1989). Language and ethnicity in minority sociolinguistic perspective. Clevedon, England: Multilingual Matters.

Gokarn, S. (2008). Studying the usage of Hinglish in brand communication in India (Doctoral dissertation). Retrieved from ProQuest. (UMI No. 1528434)

Guilloteaux, M. J., \& Dörnyei, Z. (2008). Motivating language learners: A classroom-oriented investigation of the effects of motivational strategies on student motivation. TESOL Quarterly, 42(1), 55-77.

Gumperz, J. J. (1982). Discourse strategies. Cambridge: Cambridge University Press.

Heller, M. (2008). Language and the nation-state: Challenges to sociolinguistic theory and practice. Journal of Sociolinguistics, 12(4), 504-524.

Jaffe, A. (2009). Stance: Sociolinguistic perspectives. Oxford: Oxford University Press.

Languages in Egypt. (n.d.). In Gapyear. Retrieved September 25, 2015, from https://www.gapyear.com/countries/egypt/languages 
Madonsela, S. (2014). A critical analysis of the use of code-switching in Nphlapho's novel Imbali YemaNgcamane. South African Journal of African Languages, 34(2), 167-174.

Moskovsky, C., Alrabai, F., Paolini, S., \& Ratcheva, S. (2013). The effects of teachers' motivational strategies on learners' motivation: A controlled investigation of second language acquisition. Language Learning, 63(1), 34-62.

Myers-Scotton, C. (1976). Strategies of neutrality: language choice in uncertain situations. Language, 52(4), 919-941.

Myers-Scotton, C. (1993a). Social motivation for code switching: Evidence from Africa. Oxford: Oxford University Press.

Myers-Scotton, C. (1993b). Duelling languages: Grammatical structure in codeswitching. Oxford: Clarendon Press.

Myers-Scotton, C. (2010). Code Switching as indexical of social negotiations. In M. Heller (Ed.), Codeswitching : Anthropological and sociolinguistic perspectives (pp. 151-186). Berlin, DEU: Walter de Gruyter.

Nilep, C. (2006). Code switching in sociocultural linguistics. Colorado Research in Linguistics, 19(1), 1-22.

Omoniyi, T., \& White, G. (Eds.). (2006). The sociolinguistics of identity. London: Continuum Press.

Sebba, M., Mahootian, S., \& Jonsson, C. (2012). Language mixing and code-switching in writing: Approaches to mixed-language written discourse. New York: Routledge.

Silverstein, M. (2003). Indexical order and the dialectics of sociolinguistic life. Language \& Communication, 23(3), 193-229.

Singo, J. (2014). Code-switching in doctor-patient communication. Journal of Language and Communication, 8(1), 48-56.

Suleiman, Y. (2004). A war of words: Language and conflict in the Middle East. Cambridge: Cambridge University Press. 